\title{
A RARE CASE REPORT OF LYMPHANGIOMA ON SCALP
}

\author{
Mohammed Minhajuddin Harsoori'1, Shekappa C. Malagimani², K. B. Phulekar ${ }^{3}$
}

${ }^{1}$ Postgraduate, Department of General Surgery, VIMS.

${ }^{2}$ Associate Professor, Department of Surgery, VIMS.

3Professor, Department of Surgery, VIMS.

\section{ABSTRACT}

\section{BACKGROUND}

Lymphangiomas are benign, congenital lesions that develop from sequestered lymphatic sacs. They usually occur in the neck and axilla. In this paper, we report a case of lymphangioma of the scalp on extremely rare location.

\section{KEYWORDS}

Lymphangioma, Scalp.

HOW TO CITE THIS ARTICLE: Harsoori MM, Malagimani SC, Phulekar KB. A rare case report of lymphangioma on scalp. J. Evolution Med. Dent. Sci. 2016;5(90):6740-6741, DOI: 10.14260/jemds/2016/1522

\section{BACKGROUND}

Lymphangiomas are rare benign lesions, which are characterised by proliferating lymph vessels.[1] These congenital tumours develop from sequestered lymphatic sacs.[2,3] Although lymphangioma is a benign tumour, its infiltrative character complicates removal and contributes to postoperative recurrence. [1] The majority of lymphangiomas occur in the neck and the axilla. To our knowledge, this is the rare case report of a scalp lymphangioma.

\section{CASE REPORT}

A 3-year-old female patient was admitted to hospital with the chief complaint of left parietal subcutaneous swelling. This lesion was present at birth and has grown slowly since then. Her complaint was only cosmetic. At physical examination two rubbery, painless, soft, cystic, compressible swellings $5 \times 3 \mathrm{~cm}$ and $3 \times 2 \mathrm{~cm}$ in size under the scalp in the left parietal region [Fig. 1]. Neurological examination was within normal limits. The lesion was excised totally under general anaesthesia. During the operation, minimal destruction was seen on the external table. [Fig. 2] HPE shows cavernous lymphangioma.

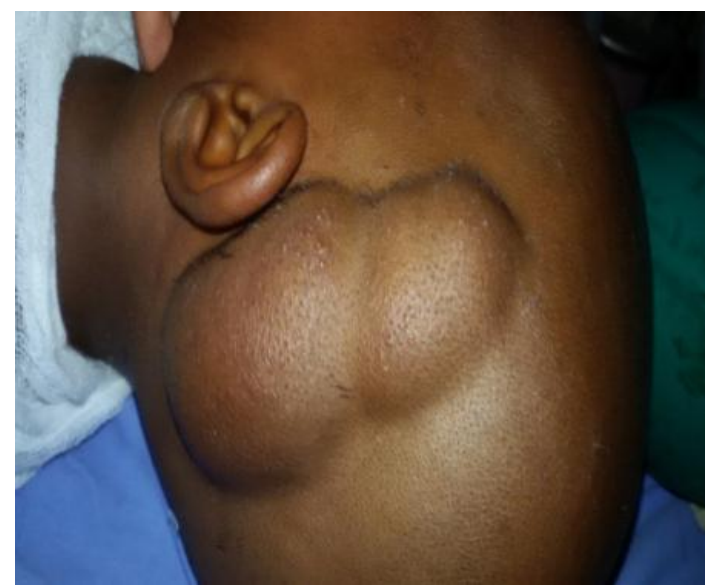

Figure 1. Scalp Lymphangioma

Financial or Other, Competing Interest: None.

Submission 17-09-2016, Peer Review 12-10-2016,

Acceptance 17-10-2016, Published 10-11-2016.

Corresponding Author:

Dr. Shekappa C. Malagimani,

$\# B / 24$, Staff Quarters,

VIMS (OPD), Cantonment, Bellary.

E-mail: doc_shekar@yahoo.com

DOI: $10.14260 /$ jemds $/ 2016 / 1522$

(c) (i) () $€$

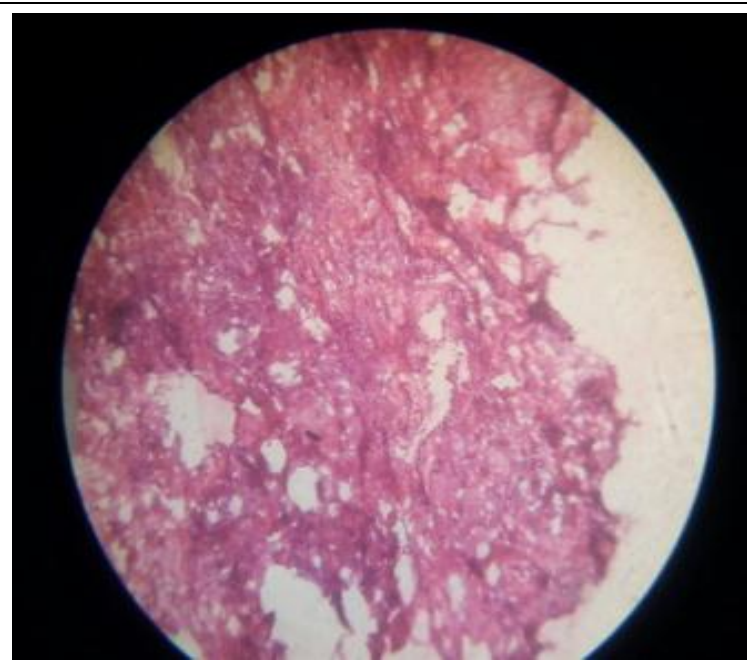

Figure 2. Histology of Lymphangioma

\section{DISCUSSION}

Lymphangiomas are slowly enlarging well circumscribed, soft, cystic tumours. They are accepted as congenital malformation/tumour-like lesions or vascular hamartomas rather than neoplasm. ${ }^{[4]}$ About $75 \%$ of lymphangiomas occur in the neck and $20 \%$ in the axillary region[1,5,6,3] in a small number of cases; other locations including the mediastinum, retroperitoneum, oral cavity, mesentery, bones and orbit have been reported.[5,7,8,6] The sexes are affected equally.[5] Usually these tumours present as easily compressible. Painless enlargements that transilluminate well.[9,7] At birth $50 \%$ are present and $90 \%$ are evident by two years of age.[6] Clinically, they may rarely bleed spontaneously.[10] Although, lymphangioma is a benign tumour, its infiltrative tendency enables it to grow along tissue planes.[1] It is usually fluctuant, lobulated and not attached to the skin but fixed to the deep tissues. Lymphangiomas consist of endothelial-lined spaces supported by a thin connective tissue base. These lesions often contain a thin, clear or straw coloured fluid, unless infected. ${ }^{[1,10]}$ If the space is contaminated by blood cells, the lesions can easily be mistaken for haemangioma. The mass may remain the same size or enlarge slowly, but spontaneous remission is very rare. ${ }^{[5,7]}$ Histologically, lymphangiomas have been classified into three types: lymphangioma circumscriptum (Papular angiokeratoma), classical lymphangioma circumscriptum (Angiokeratoma circumscriptum) and cavernous lymphangioma (Hygroma or 
cavernous haemangioma).[1,9,11,12,6] In the past, different kinds of therapy such as aspiration and injection of sclerosing agents were applied to these tumours.[13,7] Radiotherapy is unsatisfactory and is no longer used because of its failure to completely damage the tumour, but if total removal fails radiation may be indicated.[13,8]

\section{CONCLUSION}

Total surgical excision is the treatment of choice for lymphangiomas and offers the best chance of cure. $[1,13,9,5,7,14,6]$ Surgery is advised sooner rather than later, as excision is technically easier before the tumour has invaded normal tissue further and before infection has occurred and causing fibrosis and scarring. Recurrence of lymphangioma following subtotal excision is generally said to occur within one year.[13]

\section{REFERENCES}

1. Brown LR, Reiman HM, Rosenow EC, et al. Intrathoradc lymphangioma. Mayo Clin Proc 1986;61(11):882-92.

2. Poslethwaite KR. Lymphangiomas of the tongue. Br J Oral and Maxillofascial Surgery 1986;24:63-8.

3. Singh S, Baboo ML, Pathak IC. Cystic lymphangioma in children: report of 32 cases including lesions at rare sites. Surgery 1971;69(6):947-51.

4. Walter JB, Israel MS. General pathology. $6^{\text {th }}$ edn. Churchill livingstone, Edinburgh 1987:377-379.
5. Nanson EM. Lymphangioma (cystic hygroma) of mediastinum. J Cardiovasc Surg 1968;9(5):447-52.

6. Siegel MJ, Glazer HS, St Amour TE, et al. Lymphangiomas in children: MR imaging. Radiology 1989;170(2):467-70

7. Osborne TE, Levin LS, Tilghman DM, et al. Surgical correction of mandibulofasdal deformities secondary to large cervical cystic hygromas. J Oral Maxillofac Surg 1987;45(12):1015-21.

8. Rosenquist CJ, Wolfe DC. Lymphangioma of bone. J Bone and Joint Surg Am 1968;50(1):158-62.

9. Kittredge RD, Finby N. The many facets of lymphangioma. Am J Roentgenol Radium Ther Nucl Med 1965;95:56-66.

10. Coll GE, Goldberg RA, Krauss H, et al. Concomitant lymphangioma and arteriovenous malformation of the orbit. Am J OphtaI 1991;112(2):200-5.

11. Lever WF, Schaumberg-Lever G. Histopathology of the skin. $6^{\text {th }}$ edn. Philadelphia: Lippincott 1983:631-3.

12. Paletta FX. Lymphangioma. Plast Reconst Surg 1966;37:269-79.

13. Emery PJ, Bailey CM, Evans JN. Cystic hygroma of the head and neck. A review of 37 cases. J Laryngolathol Otol 1984;98(6):613-9.

14. Scallye M, Black JH. Cystic hygroma: massive recurrence in adult life. J Laryngol Otol 1990;104(11):908-10. 